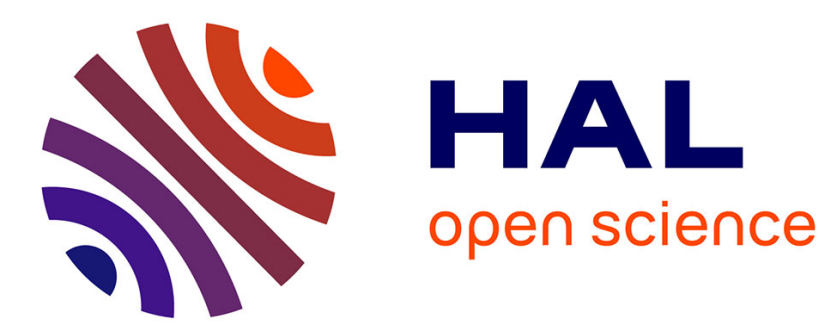

\title{
Microbial decomposition
}

Bruno Tassin, Daniel R. Thévenot

\section{To cite this version:}

Bruno Tassin, Daniel R. Thévenot. Microbial decomposition. S.E. Joegensen; M.J. Gromiec. Mathematical Submodels in Water Quality Systems, Elsevier, pp.217 - 246, 1989, Chap. 12. hal-01179690

\section{HAL Id: hal-01179690 https://hal.science/hal-01179690}

Submitted on 23 Jul 2015

HAL is a multi-disciplinary open access archive for the deposit and dissemination of scientific research documents, whether they are published or not. The documents may come from teaching and research institutions in France or abroad, or from public or private research centers.
L'archive ouverte pluridisciplinaire HAL, est destinée au dépôt et à la diffusion de documents scientifiques de niveau recherche, publiés ou non, émanant des établissements d'enseignement et de recherche français ou étrangers, des laboratoires publics ou privés. 


\section{REPRINTED FROM:}

Developments in Environmental Modelling, 14

\section{Mathematical Submodels in Water Quality Systems}

Edited by

S.E. Jørgensen

Langkaer Vaenge 9, 3500 Vaerløse, Copenhagen, Denmark

and

M.J. Gromiec

Instytut Meteorologii i Gospodarki Wodnej, 01-673 Warszawa u.

Podlesna 61, Poland

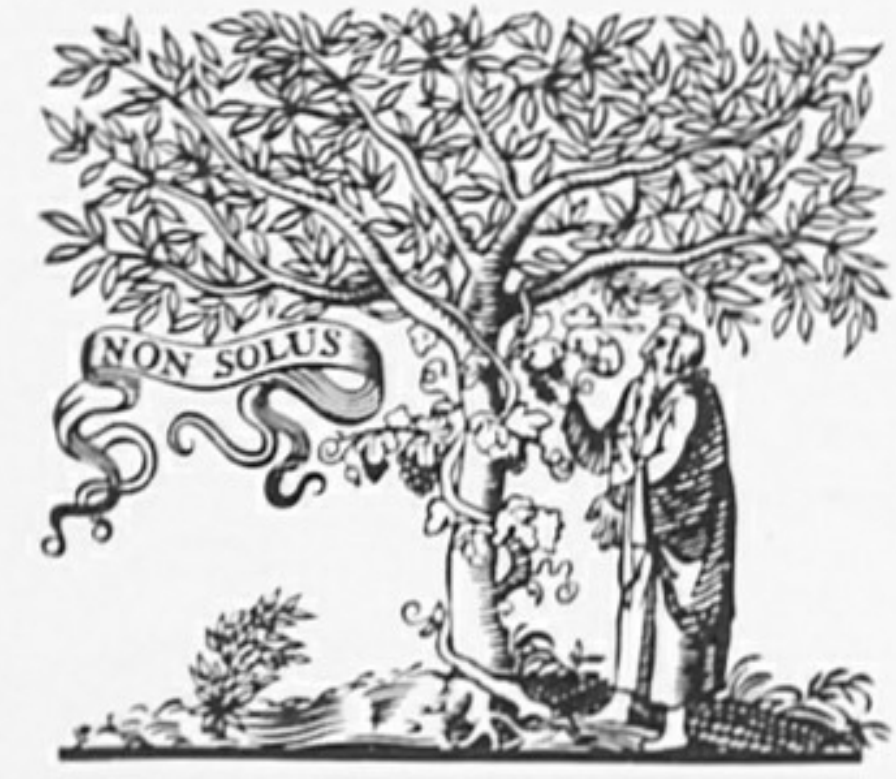

ELSEVIER

Amsterdam - Oxford - New York - Tokyo 1989 


\title{
CHAPTER 12
}

\section{MICROBIAL DECOMPOSITION}

\author{
by \\ Bruno Tassin and Daniel R. Thévenot
}

\subsection{INTRODUCTION}

Role of microbial decomposition in biodegradation processes of organic pollutants.

Within aquatic ecosystems, microbial decomposition of organic matter plays a prominent role in the energy and mass transformation processes (Jørgensen, 1983a). Organic waste water discharge in a river results in dissolved oxygen uptake, either directly by chemical oxidation of the reducing pollutants (see Chap. 10), or by their metabolism by microorganisms, i.e. their biodegradation. Raising the temperature of rivers reduces oxygen solubility and accelerates the kinetics of chemical and microbiological oxygen and polluting load reduction.

Several terms are used to describe globally these processes. Self-purification is a neutral expression, meaning elimination of dissolved or particulate matter with "polluting" properties, irrespective of the mechanism involved (Wuhrmann, 1972). Biodegradation is a more commonly accepted term which describes alterations of a compound sufficiently important to change its identity (Dart and Stretton, 1980). All biodegradable compounds are ultimately converted into one of the very few key intermediates such as acetyl-coenzyme $A$ or one of the tricarboxylic acid cycle intermediates before total oxidation occurs. As such compounds are also used for the resynthesis of larger molecules, only a portion of biodegradable compounds are totally oxidized to inorganic constituents.

Water, soil, sewage and mud are extremely complex environments biologically, chemically and physically (Dart and Stretton, 1980). Large numbers of organisms from different species and genera may be present displaying a wide range of degradative abilities. The organisms may show a spectrum of interactions, ranging from predation through commensalism to synergism. The presence or absence of predators, parasites or hosts may cause microbial populations to fluctuate over a wide range. This chapter will not describe such microbial decomposition at a biological level, but will present mathematical and experimental submodels used to simulate this wide range of interacting processes. 
A large part of waste water disposal regulations refers to the ability of various organic wastes to be biodegraded in the ecosystem. Various procedures have been developed for the measurement of biodegradability of chemical compounds, either in the innoculated die-away tests where water, salts and biomass is incubated during 5 to 40 days with the tested substance, or with activated sludge test methods where large amounts of biomass and additional organic substrates are continously fed with air or oxygen for better adaptation ot large amounts of substrates (Blok, 1975). Such tests were proposed for monitoring either carbon dioxide formation or oxygen consumption in oxygen regulated "Sapromat" respirometric cells (Remiche and Van der Wielen, 1975). In the former case, an alternative to barium carbonate measurement is the direct monitoring of ${ }^{14} \mathrm{CO}_{2}$ formation from traces of ${ }^{14} \mathrm{C}$ radiolabelled organic compounds, such as amines (Boethling and Alexander, 1979). The simultaneous monitoring of carbon dioxide and oxygen allows discrimination between microbial decomposition and chemical oxidation.

\section{Determination of parameters related to biodegradation: dissolved oxygen (DO), organic matter (OM) and biomass (B).}

Since organic pollution control has been the first concern in water quality studies and regulations parameters relating to biodegradation are relatively well defined.

Dissolved oxygen (DO) is easily determined either with absolute chemical methods such as the Winkler volumetric titration using manganous and iodide salts in basic media, or with relative electrochemical methods using Clark-type electrode, i.e. cathodic reduction of oxygen diffusing through an hydrophobic membrane.

If DO may easily and rapidly be monitored with a precision better then $1-2 \%$, organic matter $(O M)$ represents a large variety of compounds and may not be determined without ambiguity. Several methods have appeared, each of them corresponding to a given goal. The Biochemical Oxygen Demand test (BOD) intends to assess the pollutional potential of a waste water which contains an available organic carbon source for aerobic organotrophic microorganisms, by measuring the amount of oxygen utilized during growth of the organisms in a sample of waste water (Gaudy, 1972). Standard methods for measuring BOD have been described and compared. DO variations are usually measured in diluted samples after 5 or 21 days incubation at $20^{\circ} \mathrm{C}$ (Stack, 1972 and 1973); alternatively', automatic respirometers enable the direct recording of oxygen consumption of undiluted samples. In the Warburg method, gas volume variations are monitored, whether in Marais or 
"Sapromat" methods, and oxygen is supplied to the sample so that its concentration remains constant throughout the incubation test (Mytelka and Brenner, 1969; Remiche and Van der Wielen, 1975; Hung and Eckenfeld, 1976; Illic, 1978). The term 'ultimate BOD' is usually referred to in 21-days incubation tests - this test duration being necessary for total biodegradation of nitrogen-containing compounds (Stack, 1972). Nevertheless, as nitrogeneous compounds are often specifically measured and their microbial decomposition kinetics taken into account (see $\S 2.2 .1$ ), carbonaceous $\mathrm{OM}$ is then estimated by 5 days $\mathrm{BOD}$, called $\mathrm{BOD}_{5}$. The amount of $\mathrm{OM}$ may alternatively be determined either by chemical oxidation in standard conditions, such as $2 \mathrm{hr}$ ebullition with excess bichromate in sulphuric acid (Chemical Oxygen Demand, COD) (Green et al., 1981), or by total oxidation by oxygen at $900^{\circ} \mathrm{C}$, or by persulphate in the presence of heavy UV radiation (Total Oxygen Demand, TOD) (Clark, 1974); finally the carbon dioxide released during such total oxidation procedures is monitored in various ways. Carbonaceous compounds present in organic pollutants may be determined by their Total Organic Carbon (TOC). Since the OM content in surface water and in waters generally is of great economic and ecological importance, BOD, COD, TOD and TOC have been thoroughly studied and "mixed" methods with the accuracy of chemical titration have been proposed (Stack, 1973).

Biomass concentration (B) is even more difficult to determine than OM. Numerous methods have been developed, but none of them is generally accepted by the scientific community. Adenosine Triphosphate (ATP) is frequently chosen for evaluation of biomass. Indeed it is a fundamental constituent of all living cells, and only living ones, since it is destroyed very rapidly after cell death. It has been shown that the amount of ATP is proportional to the amount of cell organic carbon, which is the usual indicator of biomass: 0.30 to $0.39 \mathrm{~g} \mathrm{ATP}$ is contained in $100 \mathrm{~g}$ cell organic carbon of algae and bacteria of different sizes and species (Holm-Hansen, 1970). Furthermore, trace amounts of ATP can be easily determined by bioluminescence, after cell filtration and extraction." When mixed with luciferine and luciferase, ATP extracts yield light emission in which the intensity maximum is proportional to the ATP amount, with the lower detection limit being as low as $10^{-12} \mathrm{~mol}$ (Tobin et al., 1978; Apoteker, 1981). But an alternative to ATP determination has been proposed Deoxyribonucleic acid (DNA) content, though this rarely used for biomass estimation since it is known to retain its concentration level even after cell death. Finally, when phytoplanktonic biomass is to be determined, chlorophyl $s$ are measured after cell filtration and extraction. 


\section{Different types of kinetic models of microbial decomposition.}

Numerous kinetic models of water quality have been proposed to describe DO and BOD variations along a stream (Gromiec et al., 1983; Gromiec, 1983) in lakes or reservoirs (Orlob, 1983, Jørgensen, 1983b) and in waste water treatment processes. The first, and most widely used model, was proposed by Streeter and Phelps (1925) for the Ohio river. It states that oxygen uptake is equal to BOD uptake, and that both kinetics are first-order. Since then several modifications have been proposed to take into account the effect of dispersion (O'Connor, 1961, 1962, 1967), sedimentation and adsorption (Dobbins, 1964), photosynthesis and respiration (O'Connor and Di Torro, 1970), thermal exchanges (Lin et al., 1973a, b, c), bental demand (Shelton et al., 1978) and nitrogeneous biodegradation (Shelton et al., 1978; Knowles and Wakeford, 1978). Nevertheless, it has been frequently observed that firstorder curves do not fit well the experimental variations of BOD, so that second-order kinetics were proposed for DO and BOD uptakes (Woodward, 1953; Revelle et al., 1965; Young and Clark, 1965; Zanoni, 1967; Edeline and Lambert, 1979). Their success in describing actual river evolution was not generally accepted.

Beside these field studies, Flegal and Schroeder (1976), Rauwel and Thévenot (1976) and Apoteker and Thévenot (1983) conducted laboratory experiments without renewal of DO: after organic discharges. All these authors observed lag-phases with no oxygen evolution, followed by exponential phases, similar to those encountered in experiments on cellular growth.

First-order kinetic models: Streeter-Phelps, O'Connor, Dobbins, Lin and Shelton models; examples and discussion.

Streeter and Phelps (1925) kinetic model of DO and BOD evolution in streams is based upon two main assumptions: firstly, both microbial decomposition of $\mathrm{OM}$ and reoxygenation of water by the atmosphere follow first-order kinetics; second, microbial DO and BOD uptakes are equal whatever the stage of OM decomposition and the type of OM. Taking these two assumptions as valid, two kinetic equations may be written:

$$
\begin{aligned}
& \mathrm{dL} / \mathrm{dt}=-\mathrm{K}_{1} \mathrm{~L} \\
& \mathrm{dC} / \mathrm{dt}=-\mathrm{K}_{1} \mathrm{~L}+\mathrm{K}_{2}\left(\mathrm{C}_{\mathrm{s}}-\mathrm{C}\right)
\end{aligned}
$$


where

$L$ is the OM load, usually estimated as ultimate BOD, i.e. 21 days BOD $\left(M L^{-3}\right)$, $C$ is the DO concentration $\left(\mathrm{M} \mathrm{L}^{-3}\right)$ at time $t(T)$,

$\mathrm{C}_{\mathrm{s}}$ is the saturated $\mathrm{DO}$ concentration $\left(\mathrm{M} \mathrm{L}^{-3}\right)$ at the water temperature $\mathrm{T}$,

$\mathrm{K}_{1}$ is the first-order biodegradation kinetic constant, also called deoxygenation rate constant $\left(\mathrm{T}^{-1}\right)$,

$\mathrm{K}_{2}$ is the first-order oxygen transfer or reaeration kinetic constant $\left(\mathrm{T}^{-1}\right)$.

As presented later in this paragraph and in $\S 3.1, \mathrm{~K}_{1}$ frequently does not take into account BOD excretion by nitrogeneous compounds and by sediments.

As DO concentration is frequently replaced by oxygen saturation deficit, $\mathrm{D}=\mathrm{C}_{\mathrm{s}}-\mathrm{C}$, equation (12.2) becomes:

$\mathrm{dD} / \mathrm{dt}=\mathrm{K}_{1} \mathrm{~L}-\mathrm{K}_{2} \mathrm{D}$

The solutions to (12.1) and (12.3) are:

$L=L_{0} \exp \left(-K_{1} t\right)$

$D_{t}=\frac{K_{1} L_{0}}{K_{2}-K_{1}^{-}}\left(\exp \left(-K_{1} t\right)-\exp \left(-K_{2} t\right)\right)+D_{0} \exp \left(-K_{2} t\right)$

where

$D_{t}$ is the dissolved oxygen saturation deficit after time $t$,

$L_{o}$ is the BOD at an initial reference time $(t=0)$,

$D_{0}$ is the dissolved oxygen deficit at $t=0$.

Kinetic constants $\mathrm{K}_{1}$ and $\mathrm{K}_{2}$ are sometimes replaced by

$\underline{\mathrm{k}}_{1}=0.434 \mathrm{~K}_{1} \quad$ and $\underline{\mathrm{k}}_{2}=0.434 \mathrm{~K}_{2}$

when exponential functions of (12.5) are replaced by power of 10 functions. Equation 12.5 is the Streeter-Phelps "oxygen sag formula" and a profile of DO along a stream is referred to as a "dissolved oxygen sag curve" (Figure 12.1). The critical point of this curve corresponds to the minimum of DO or the maximum of saturation deficit $D_{c}$, reached at critical time $t_{c}$. At this point $\mathrm{dD} / \mathrm{dt}=0$, and the critical deficit is

$$
D_{c}=\frac{K_{1}}{K_{2}} L=\frac{K_{1}}{K_{2}} L_{0} \quad \exp \left(-K_{1} t_{c}\right)
$$


and the critical time equals

$$
t_{c}=\frac{1}{K_{2}-K_{1}} \operatorname{Ln}\left(\frac{K_{2}}{K_{1}}-\left(1-\frac{D_{0}\left(K_{2}-K_{1}\right)}{L_{0} K_{1}}\right)\right)
$$

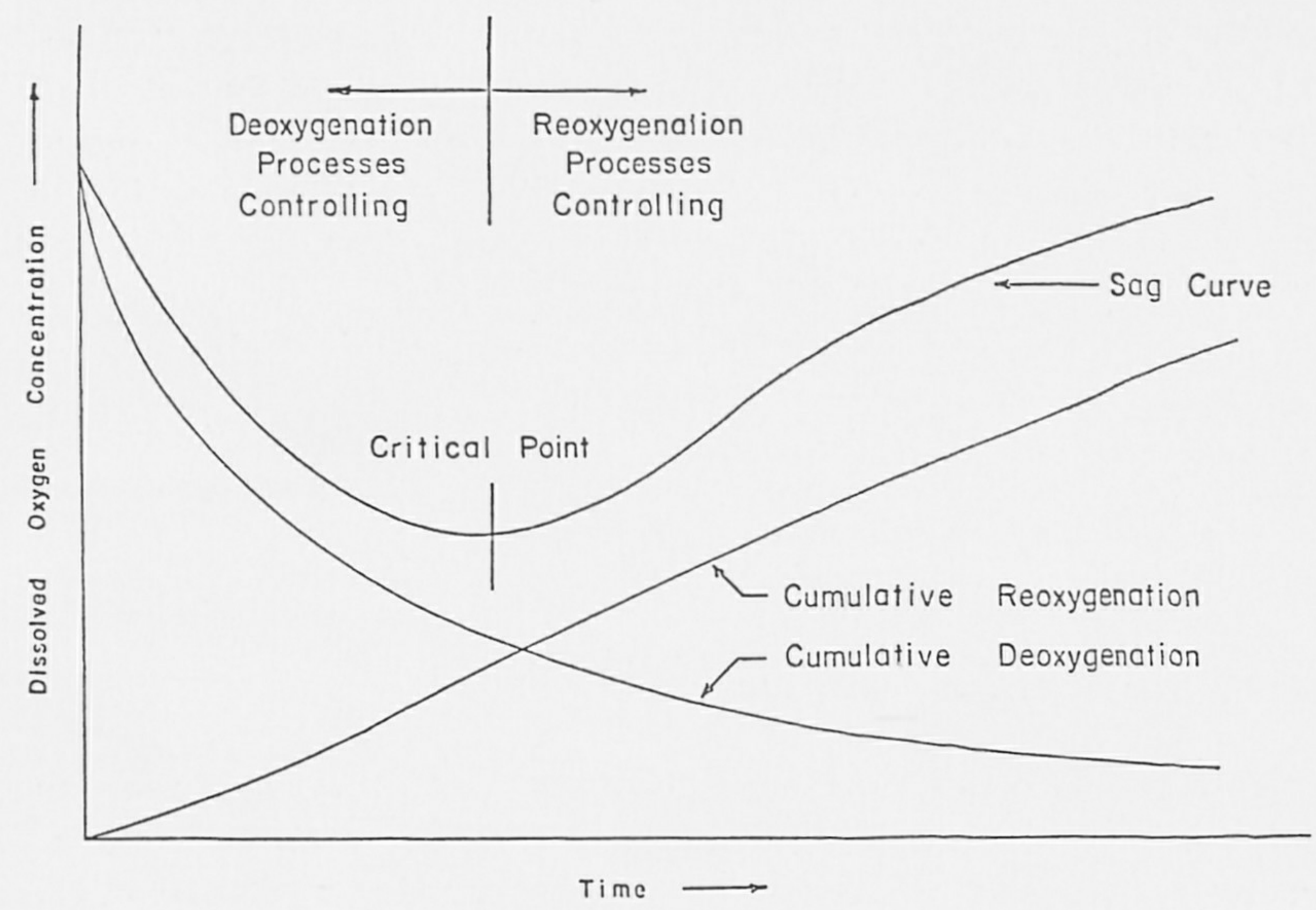

Classical Oxygen sag Curve With Deoxygenation and Reokygenation

Fig. 12.1: Dissolved oxygen sag curve using first-order kinetics. After Gates (1971).

Equations 12.6 and 12.7 are sometimes simplified, using the Fair coefficient $f=K_{2} / K_{1}$, also called the self-purification factor:

$$
\begin{aligned}
& t_{c}=-\frac{1}{K_{1}(f-1)}-\operatorname{Ln}\left(f\left(1-(f-1) \frac{D_{0}}{L_{0}}\right)\right) \\
& D_{c}=\frac{L_{0}}{f}-\left(f\left(1-(f-1) \frac{D_{0}}{L_{0}}\right)\right)^{1 /(1-f)}
\end{aligned}
$$

Arababi et al. $(1974,1975)$ have given a linear approximation of $D_{c}$ in relation to the initial oxygen deficit and pollution load

$D_{c}=R L_{0}+A D_{0}$

with 


$$
R=f^{f /(1-f)} \text { and } A=1-f^{1 /(1-f)}
$$

this approximation, better than $6.2 \%$, being very usefull for water quality assessment studies.

Besides the two previously mentioned assumptions, the Streeter-Phelps model is based on a constant pollution load discharged at a single given point along a stream having a constant flow rate $Q$ and uniform cross section. The lateral and vertical DO and BOD concentrations are assumed uniform throughout any cross section. Within lakes and reservoirs such assumptions are obviously erroneous. Water stratification, related to temperature gradients, play frequently a prominent role in lake water quality models. Thus equations 12.4 to 12.9 are mainly used for stream water quality models.

Since 1925 when the Streeter-Phelps kinetic model was presented, numerous modifications and improvements have been incorporated withou: changing the first-order kinetic basic assumptions.

\section{Nitrogeneous compounds biodegradation.}

When BOD tests are performed with waste water samples containing nitrogeneous compounds such as organic nitrogen (amines, amides, proteins) or ammonium salts, oxygen evolution curves, recorded on Sapromat or respiration equipments, frequently present two steps (Figure 12.2). The second step, significant after 7-10 days, is attributed to nitrogen containing compound from microbial decomposition, i.e. organic nitrogen mineralisation and ammonium nitrification.

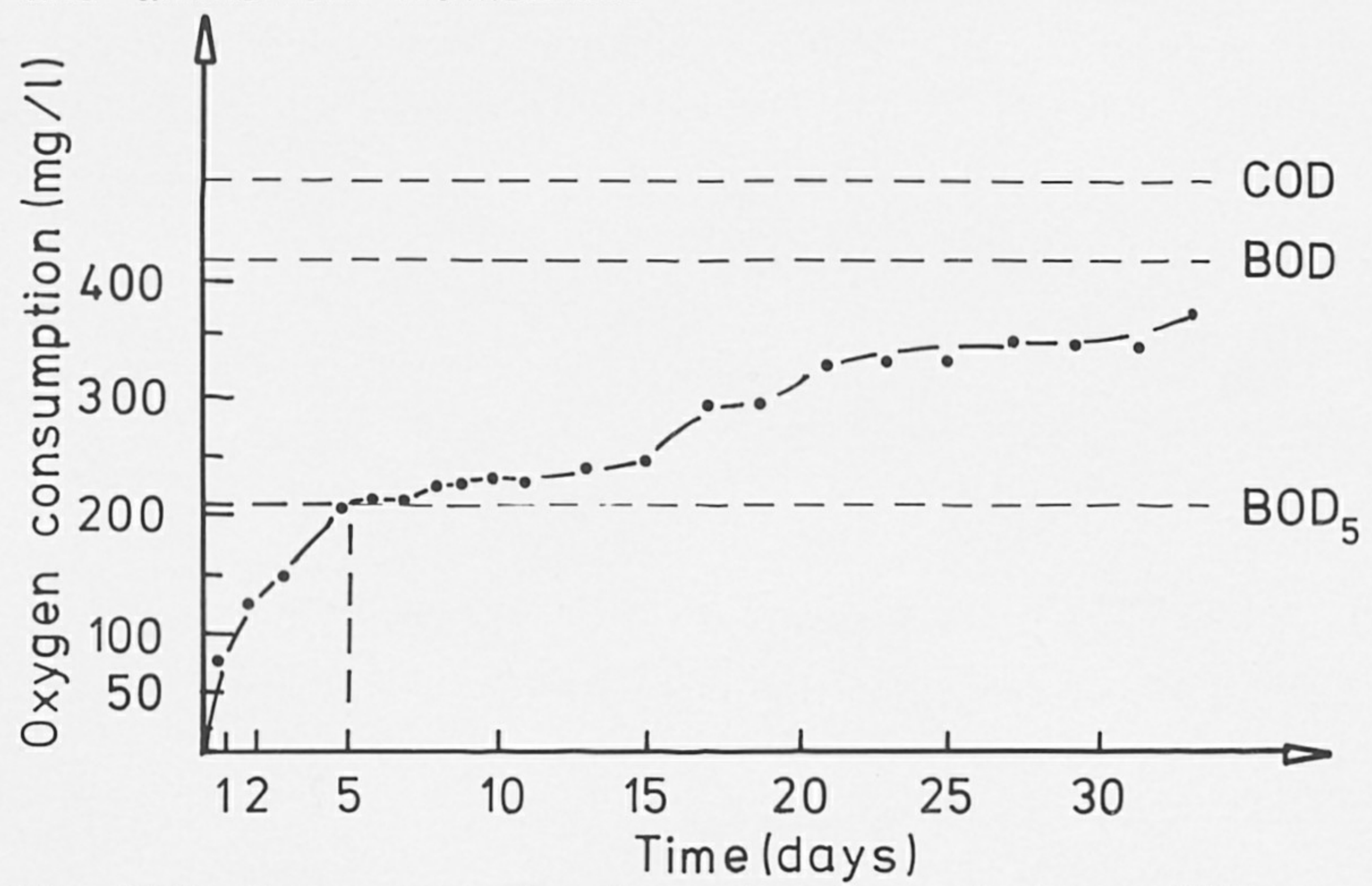

Fig. 12.2: Oxygen consumption of a waste water sample during a BOD test. After Wilderer et al. (1970). 
As microbial decomposition of nitrogen-containing compounds is known to occur more slowly than carbonaceous biodegradation, the Streeter-Phelps kinetic models may incorporate in $\mathrm{OM}$ and DO uptake kinetic equations 12.1 and 12.2 specific terms for each form of nitrogen $\left(\mathrm{O}^{\prime}\right.$ Connor and $\mathrm{Di}$ Toro, 1970; Shelton et al., 1978):

$$
\begin{aligned}
& \mathrm{d}\left(\mathrm{NH}_{4}-\mathrm{N}\right) / \mathrm{dt}=\mathrm{K}_{1, \mathrm{NH}_{4}}\left(\mathrm{NH}_{4}-\mathrm{N}\right) \\
& \mathrm{d}\left(\mathrm{NO}_{2}-\mathrm{N}\right) / \mathrm{dt}=\mathrm{K}_{1, \mathrm{NO}_{2}}\left(\mathrm{NO}_{2}-\mathrm{N}\right) \\
& \mathrm{dD} / \mathrm{dt}=\mathrm{K}_{1} \mathrm{~L}+4.57 \mathrm{~K}_{1, \mathrm{NH}_{4}}\left(\mathrm{NH}_{4}-\mathrm{N}\right)+1.14 \mathrm{~K}_{1, \mathrm{NO}_{2}}\left(\mathrm{NO}_{2}-\mathrm{N}\right)-\mathrm{K}_{2} \mathrm{D}
\end{aligned}
$$

the numerical factors 4.57 and 1.14 being equal to the number of grams of oxygen necessary for the transformation of $1 \mathrm{~g}$ of $\mathrm{NH}_{4}-\mathrm{N}$ or $\mathrm{NO}_{2}-\mathrm{N}$ into nitrate. In equation $12.13 \mathrm{~L}$ relates to carbonaceous $\mathrm{OM}$ and is usually estimated by $\mathrm{BOD}_{5}$.

When such models have been applied to OM and DO variations in stream water, first-order kinetic constants were found to vary significantly from stream quality: $K_{1}$ ranges between 0.09 and 0.64 day $^{-1}$ (the lowest values being obtained in non-polluted rivers) (Eckenfelder, 1970; Hung et al., 1978) and $\mathrm{K}_{1, \mathrm{NH}_{4}}$ ranges between 0.07 and 0.14 day $^{-1}$ (Lefort, 1971). In fact when values of $\mathrm{DO}, \mathrm{OM}, \mathrm{NH}_{4}-\mathrm{N}$ and $\mathrm{NO}_{2}-\mathrm{N}$ are measured along a stream section of homogeneous properties at initial and ' $\mathrm{t}$ ' time, $\mathrm{K}_{1}, \mathrm{~K}_{2}, \mathrm{~K}_{1, \mathrm{NH} 4}$ and $\mathrm{K}_{1, \mathrm{NO} 2}$ are determined from best fit of the data (Rinaldi and Soncini-Sessa, 1977).

Besides this specific introduction of nitrogenous compound biodegradation, the Streeter-Phelps kinetic model has received several sets of modifications and improvements which nevertheless do not change its first-order character.

\section{Dispersion and transport.}

O'Connor (1961, 1962, 1967) introduced Fick's diffusion law in BOD and DO profiles:

$$
\begin{aligned}
& \frac{d L}{d t}+\frac{v d L}{d x}-\frac{E d^{2} L}{d x^{2}}=-K_{1} L \\
& \frac{d C}{d t}+\frac{v d C}{d x}-\frac{E d^{2} C}{d x^{2}}=-K_{1} L+K_{2}\left(C_{s}-C\right)
\end{aligned}
$$


where

$v \quad$ is the stream velocity $\left(L T^{-1}\right)$

$E$ is the turbulent transport (longitudal mixing) coefficient $\left(\mathrm{L}^{2} \mathrm{~T}^{-1}\right)$

\section{Sediments}

Dobbins (1964) introduced the BOD removal by sedimentation and/or adsorption with a first-order kinetic constant $\mathrm{K}_{1, \mathrm{~s}}$ and the removal of $\mathrm{DO}$ by benthic processes and by plant respiration/photosynthesis:

$$
\begin{aligned}
& \frac{d L}{d t}+\frac{v d L}{d x}-\frac{E d^{2} L}{d x^{2}}=-\left(K_{1}+K_{1, s}\right) L \\
& \frac{d C}{d t}+\frac{v d C}{d x}-\frac{E d^{2} C}{d x^{2}}=-K_{1} L+K_{2}\left(C_{s}-C\right)-D_{b}
\end{aligned}
$$

where

$\mathrm{K}_{1, \mathrm{~s}}$ is the kinetic constant of BOD evolution on sediments $\left(\mathrm{T}^{-1}\right)$

$D_{b}$ is the rate of removal of DO caused by benthic demand and plants

$$
\left(\mathrm{M} \mathrm{L}^{-3} \mathrm{~T}^{-1}\right. \text { ) }
$$

The water exertion rate of BOD in streams, including all sinks such as sediments, is usually refered to as $\mathrm{K}_{1, r}$. Thus one may replace in equation (12.16) $\mathrm{K}_{1}+\mathrm{K}_{1, \mathrm{~s}}$ by $\mathrm{K}_{1, \mathrm{r}}$ if other terms such as resuspension or volatilisation of $\mathrm{OM}$ are neglected.

\section{Photosynthesis and respiration}

O'Connor and $\mathrm{Di}$ Toro (1970) adjusted the temporal form of the photosynthetic oxygen source in streams by a half-cycle sine wave. The daily rate of photosynthetic oxygen production $P$ as a function of time was expressed as:

$$
\begin{array}{ll}
\left.P=P_{m} \sin (p i / s)\left(t-t_{s}\right)\right) & \text { when } t_{s} \leq t \leq t_{s}+s \\
P=0 & \text { when } t_{s}+s \leq t \leq t_{s}+1
\end{array}
$$

where

$P_{m}$ is the maximum oxygen photosynthesis, in the stream $\left(M^{-3} \mathrm{~T}^{-1}\right)$

$t_{s}$ is the time, expressed as a fraction of the day, at which the source 
becomes active ( $T$ )

$s$ is the fraction of the day during which the source is active (period of sunlight) ( $T$ ).

Taking into account the benthic and algal respiration rate and the algal photosynthesis, the DO equation becomes:

$$
\frac{v d C}{d x}-\frac{E d^{2} C}{d x^{2}}=-K_{1} L+K_{2}\left(C_{s}-C\right)-S-R+P
$$

where

$S=$ a function of distance $x$, is the benthic respiration rate $(\operatorname{sink})\left(M L^{-3} T^{-1}\right)$

$R=a$ function of distance $x$, is the algal respiration rate (sink) $\left(M^{-3} \mathrm{~L}^{-1}\right)$

$P=a$ function of time $t$ and distance $x$, is the algal photosynthetic oxygen production rate (source) $\left(\mathrm{M} \mathrm{L}^{-3} \mathrm{~T}^{-1}\right)$.

Alfi et al. (1972) have determined in situ the above mentioned $S, R$ and $P$ parameters by implanting cylinder containers into a stream and recording in each of them the DO evolution. These closed cylinders were either transparent (with bottom open to sediments for benthic demand or bottom closed) or black (bottom closed) to prevent $K_{2}, S$ and $P$ influence. $K_{2}$ was determined using an unconfined oxygen probe situated in the vicinity.

\section{Thermal exchanges}

To the Dobbins model, Lin et al. (1973a, b, c) introduced a third equation representing water temperature $\mathrm{T}$ evolution:

$$
\frac{d T}{d t}-\frac{E d^{2} T}{d x^{2}}+\frac{v d T}{d x}-Q_{T}=0
$$

where $Q_{T}$ represents the air-water energy transfer rate, function of air and water temperature, specific mass and calorific capacity as well as wind velocity and radiation flux (Jacquet, 1983) (see Chap. 5).

\section{Waste water discharge}

Lin et al. (1973b) introduced also a continuous discharge of wastes along the stream and modified equation (12.14):

$\frac{d L}{d t}+\frac{v d L}{d x}-\frac{E d^{2} L}{d x^{2}}=-K_{1} L+L_{a}$ 
where $L_{a}$ is the rate of BOD release along a river length unit $\left(M^{-4}\right)$.

\section{Discussion}

Whatever the improvements brought to the original Streeter-Phelps kinetic equations (12.1) and (12.2), all these models suffer from the two basic assumptions mentioned above. If one summarizes microbial decomposition processes by a biomass catalysed overall reaction

$$
\mathrm{OM}+\mathrm{O}_{2} \longrightarrow \text { products }
$$

then, assuming a first-order kinetic of $\mathrm{OM}$ evolution means that reaction (12.22) is independent of DO and biomass concentration:. This is obviously erroneous, and in contradiction to any experimental microbial reaction kinetics. Both DO and B levels play a prominent role in aerobic biodegradation reactions (Gates, 1971; Wuhrmann, 1972; Edeline and Buet, 1978; Edeline and Lambert, 1979; Apoteker, 1981; Apoteker and Thévenot, 1983). Furthermore microbial metabolism as well as cell culture experiments demonstrate that the substrates and oxygen demands by microorganism are not proportional to but depend upon the cell development state.

As literature contains numerous reports of field studies in which the Streeter-Phelps kinetic models are used with reasonable success, there is an apparent contradiction between field and laboratory studies. Validity of experimental simulation methods for self-purification studies (Gates, 1971; Edeline and Lambert, 1974) and of cell culture kinetics does not seem to be questionable. Thus the apparent validity of first-order models may be related to the lack of precision of field determinations of concentration parameters such as $C, L$ or $T$ and even more dramatically to the very approximate evaluation of waste fluxes and quality, i.e. $L_{0}$ and/or $L_{a}$.

Within lakes and reservoirs the main processes taken into account for water quality modelling are usually eutrophication reactions related to phosphorus and nitrogen cycles. In such systems the absence of any kinetic relation to biomass evolution is obviously erroneous. On the other hand, most stream kinetic models used in environmental assessment studies neglect eutrophication processes and biomass evolution:. Field data seem reasonably well fitted with previously mentioned Streeter-Phelps first-order kinetic models. 


\section{Zero-order kinetic models; examples and discussion}

When Seine River water DO and BOD was modelled by Lesouef (1981), it was found that, although first-order kinetic models provided a good fit above the Paris general sewage plant at Achères, below that point zero-order BOD kinetics seem to fit much better. Equation (12.13) becomes:

$$
\frac{\mathrm{dD}}{\mathrm{dt}}=\mathrm{K}_{1}+4.57 \mathrm{~K}_{1, \mathrm{NH} 4}\left(\mathrm{NH}_{4}-\mathrm{N}\right)-\mathrm{K}_{2} \mathrm{D}
$$

One should point out that for very slow biodegradation processes there is no large difference between first- and zero-order kinetics and this seems to be the case in the Seine River below Achères general sewage plant of Paris.

Furthermore, Lesouef (1979) demonstrated that the ammonium uptake first-order kinetic constant $\mathrm{K}_{\mathrm{NR}, \mathrm{NH} 4}$ was frequently two times larger than the ammonium oxidation (nitrification) kinetic constant $\mathrm{K}_{1, \mathrm{NH}_{4}}$. Indeed ammonium uptake correspond to nitrification but also to assimilation or even ammoniac evaporation reactions. For this equations (12.11) (12.23) and (12.5) become:

$$
\begin{aligned}
& \frac{d\left(\mathrm{NH}_{4}-\mathrm{N}\right)}{d t}=-\mathrm{K}_{\mathrm{NR}, \mathrm{NH} 4}\left(\mathrm{NH}_{4}-\mathrm{N}\right) \\
& \frac{\mathrm{dD}}{\mathrm{dt}}=\mathrm{K}_{1}+4.57 \mathrm{~K}_{1, \mathrm{NH} 4}\left(\mathrm{NH}_{4}-\mathrm{N}\right)_{0} \exp \left(-\mathrm{K}_{\mathrm{NR}, \mathrm{NH} 4} \mathrm{t}\right)-\mathrm{K}_{2} \mathrm{D} \\
& D_{t}=\frac{4.51 \mathrm{~K}_{1, N H 4-N}\left(\mathrm{NH}_{4}-\mathrm{N}\right)_{0}}{\mathrm{~K}_{2}-\mathrm{K}_{\mathrm{NR}, \mathrm{NH} 4-\mathrm{N}}}\left(\exp \left(-\mathrm{K}_{\mathrm{NR}, \mathrm{NH} 4-\mathrm{N}} \mathrm{t}\right)-\exp \left(-\mathrm{K}_{2} \mathrm{t}\right)\right) \\
& +\frac{\mathrm{K}_{1}}{\mathrm{~K}_{2}}\left(1-\exp \left(-\mathrm{K}_{2} \mathrm{t}\right)\right)+\mathrm{D}_{0} \exp \left(-\mathrm{K}_{2} \mathrm{t}\right)
\end{aligned}
$$

with $\mathrm{K}_{1}$ at $20^{\circ} \mathrm{C}$ equal to $1.4 \mathrm{mg} \mathrm{l}^{-1} \mathrm{day}^{-1}$ and $\mathrm{K}_{\mathrm{NR}, \mathrm{NH} 4}$ equal to 0.11 and 0.06 day $^{-1}$ in spring-summer and in autumn respectively.

When first-order kinetics are used for $\mathrm{DO}, \mathrm{BOD}$ and $\mathrm{NH}_{4}$ evolution, as well as for ammonium nitrification, equations (12.23), (12.25) and (12.26) become: 


$$
\begin{aligned}
& \frac{d D}{d t}=K_{1} L+4.57 K_{1, N H 4}\left(N_{4}-N\right)-K_{2} D \\
& \frac{d D}{d t}=K_{1} L_{0} \exp \left(-K_{1} t\right)+4.57 K_{1, N H 4}\left(N_{4}-N\right)_{0} \exp \left(-K_{N R, N H 4} t\right)-K_{2} D \\
& D_{t}=\frac{4.51 K_{1, N H 4-N}\left(N_{4}-N\right)_{0}}{K_{2}-K_{N R, N H 4-N}}\left(\exp \left(-K_{N R, N H 4-N} t\right)-\exp \left(-K_{2} t\right)\right) \\
& +\frac{K_{1} L_{0}}{K_{2}-K_{1}}\left(\exp \left(-K_{1} t\right)-\exp \left(-K_{2} t\right)\right)+D_{0} \exp \left(-K_{2} t\right)
\end{aligned}
$$

with $K_{1}$ ranging between 0.4 and 0.6 day $^{-1}$.

Such zero-order kinetic models for DO evolution in highly polluted streams seem to be only related to attempts to fit correctly sets of field data. They are not based on chemical or microbiological kinetic assumptions.

\subsection{PARAMETERS ESTIMATION}

\section{Determination of the reaeration kinetic constant $\mathrm{K}_{2}$}

Although this point has been already considered in the Chapter 3 , the most recent methods of calculation of the reaeration kinetic constant $\mathrm{K}_{2}$ will be presented here. It will also be assumed that the reoxygenation will occur at the interface air-water and follow a first order kinetic law:

$$
\frac{d R_{0}}{d t}=K_{2}\left(C_{s}-C\right)
$$

where

$\mathrm{dR}_{0} / \mathrm{dt}$ is the rate of reoxygenation $\left(\mathrm{M} \mathrm{L}^{-3} \mathrm{~T}^{-1}\right)$

$\mathrm{C}_{\mathrm{S}}$ is the concentration of oxygen at saturation $\left(\mathrm{M} \mathrm{L}^{-3}\right)$

$\mathrm{C}$ is the concentration of oxygen in the river $\left(\mathrm{M} \mathrm{L}^{-3}\right)$

$\mathrm{K}_{2} \quad$ is the reaeration kinetic constant $\left(\mathrm{T}^{-1}\right)$.

The reaeration kinetic constant is influenced by many factors. The most important to be considered are: (see Chapter 3 for further details) 

a. the water temperature $\mathrm{T}$
b. the river flow characteristics (flow velocity $v$, depth of the river $H$ )
c. the meteorological characteristics (air temperature and wind velocity)

a. The water-temperature $T$ dependence of the reaeration coeffient $K_{2}$ is usually assumed to follow an Arrhenius-type law:

$$
\mathrm{K}_{2}=\left(\mathrm{K}_{2}\right)_{20} \text { theta }{ }^{(\mathrm{T}-20)}
$$

where

$\mathrm{T}$ is the temperature of the water $\left({ }^{\circ} \mathrm{C}\right)$,

$\left(\mathrm{K}_{2}\right)_{20}$ is the value of $\mathrm{K}_{2}$ at $20^{\circ} \mathrm{C}\left(\mathrm{T}^{-1}\right)$, and

theta is a dimensionless parameter varying from 1.008 (Truesdale et ai., 1958) to 1.046 (Streeter et al., 1936).

b. The influence of two parameters characteristic of the river flow (stream velocity and depth) on $\mathrm{K}_{2}$ was investigated by Covar, 1976.

A graph has been plotted of the data collected by O'Connors et al. (1958; Churchill et al. (1968) and Owens et al. (1964), as presented in Chapter 3.

Table 12.1 presents some reaeration coefficient values for rivers and streams of different depth and velocities.

\section{Determination of the biodegradation kinetic constant $K_{1}$}

Numerous methods have been developed and used to determine the biodegradation kinetic constant rate, $\mathrm{K}_{1}$, of the first-order Streeter-Phelps kinetic model. Three different rates can be found in the literature (Bowie et al., 1985):

$\mathrm{K}_{1}$ water deoxygenation rate due to BOD exertion $\left(\mathrm{T}^{-1}\right)$

$\mathrm{K}_{1, \mathrm{I}}$ laboratory deoxygenation rate due to $\mathrm{BOD}$ exertion $\left(\mathrm{T}^{-1}\right)$

$\mathrm{K}_{1, \mathrm{r}}$ water $\mathrm{BOD}$ exertion rate, including all sinks $\left(\mathrm{T}^{-1}\right)$

The significance of these three parameters is very different and has to be taken into account when a model is built up. 
Table 12.1

Reaeration coefficient $\mathrm{K}_{2}$ for different rivers and streams. After Hydroscience (1971)

\begin{tabular}{|c|c|c|c|c|c|c|c|}
\hline River name & Category & $\begin{array}{l}\text { Depth } \\
\text { (m) }\end{array}$ & $\begin{array}{l}\text { Area } \\
\left(\mathrm{m}^{2}\right)\end{array}$ & $\begin{array}{l}\text { Flow } \\
\left(\mathrm{m}^{3} / \mathrm{s}\right)\end{array}$ & $\begin{array}{l}\text { Velocity } \\
(\mathrm{m} / \mathrm{s})\end{array}$ & $\begin{array}{c}\mathrm{K}_{2} 20^{\circ} \mathrm{C} \\
\text { (I/day) }\end{array}$ & Reference \\
\hline $\begin{array}{l}\text { Grand River } \\
\text { (Michigan) }\end{array}$ & Shallow & 0.579 & 29.729 & 8.336 & 0.280 & 4.500 & $\begin{array}{l}\text { O'Connor et al. } \\
\text { (1970) }\end{array}$ \\
\hline $\begin{array}{l}\text { Clinton River } \\
\text { (Michigan) }\end{array}$ & Shallow & 0.482 & 4.143 & 0.909 & 0.219 & 5.900 & $\begin{array}{l}\text { O'Connor et al. } \\
\text { (1970) }\end{array}$ \\
\hline $\begin{array}{l}\text { Truckee River } \\
\text { (Nevada) }\end{array}$ & Shallow & 0.509 & 13.935 & 7.688 & 0.552 & 6.600 & $\begin{array}{l}\text { O'Connor et al. } \\
(1970)\end{array}$ \\
\hline $\begin{array}{l}\text { Jackson River } \\
\text { (Virginia) }\end{array}$ & Shallow & 0.914 & 33.910 & 2.791 & 0.082 & 4.100 & $\begin{array}{l}\text { Hydroscience } \\
\text { (1967) }\end{array}$ \\
\hline $\begin{array}{l}\text { Ivel River } \\
\text { (GB) }\end{array}$ & Shallow & 0.369 & 3.200 & 0.138 & 0.043 & 2.350 & $\begin{array}{l}\text { Owens et al. } \\
\text { (1962) }\end{array}$ \\
\hline $\begin{array}{l}\text { Mohawk River } \\
\text { (New York) }\end{array}$ & $\begin{array}{l}\text { Inter- } \\
\text { mediate }\end{array}$ & 4.572 & 353.032 & 22.597 & 0.064 & $0.07-4.0$ & $\begin{array}{l}\text { O'Connor et al. } \\
(1968)\end{array}$ \\
\hline $\begin{array}{l}\text { New River } \\
\text { (Virginia) }\end{array}$ & $\begin{array}{l}\text { Inter- } \\
\text { mediate }\end{array}$ & 1.524 & 159.793 & 34.093 & 0.213 & 1.040 & $\begin{array}{l}\text { Hydroscience } \\
\text { (1966) }\end{array}$ \\
\hline $\begin{array}{l}\text { Clinch River } \\
\text { (T.V.) }\end{array}$ & $\begin{array}{l}\text { Inter- } \\
\text { mediate }\end{array}$ & 2.185 & 208.594 & 167.918 & 0.805 & 1.130 & $\begin{array}{l}\text { Churchill et al. } \\
\text { (1962) }\end{array}$ \\
\hline $\begin{array}{l}\text { Holston } \\
\text { (T.V.) }\end{array}$ & $\begin{array}{l}\text { Inter- } \\
\text { mediate }\end{array}$ & 3.478 & 330.416 & 294.070 & 0.890 & 0.280 & $\begin{array}{l}\text { Churchill et al. } \\
\text { (1962) }\end{array}$ \\
\hline $\begin{array}{l}\text { Wautasa } \\
\text { (T.V.) }\end{array}$ & $\begin{array}{l}\text { Inter- } \\
\text { mediate }\end{array}$ & 1.042 & 57.82 & 88.122 & 1.524 & 5.600 & $\begin{array}{l}\text { Churchill et al. } \\
\text { (1962) }\end{array}$ \\
\hline Ohio River & Deep & 9.754 & 3994.831 & 170.467 & 0.043 & 0.060 & Streeter et al. (1925) \\
\hline Upper Hudson & Deep & 6.401 & 627.096 & 286.708 & 0.457 & 0.165 & Hydroscience (1965) \\
\hline Upper James & Deep & 4.724 & 1393.546 & 55.218 & 0.040 & 0.220 & Hydroscience (1964) \\
\hline
\end{tabular}

The $\mathrm{K}_{1, \mathrm{r}}$ coefficient includes all sinks of BOD and especially the physical processes like sedimentation, floculation, resuspension and mixing, and special chemical processes like volatilization. Thus the use of $K_{1, r}$, or of $K_{1}$, in the model depends only on the system analysis of the system which is modelled. If just BOD and DO are taken into account, then $K_{1, r}$ has to be used; if the model deals specifically with nitrogen-containing species, then $\mathrm{K}_{1}$ is prefered. 


\section{Relation between $\mathrm{K}_{1}$ and $\mathrm{K}_{1,1}$}

The difference between $K_{1,1}$ and $K_{1}$ is related to the difference of flow characteristics in the river and in a BOD bottle. Many relations have been developed between these parameters. We will present two of these methods.

The first one (Nejedly, 1973) relates $K_{1, I}$ and $K_{1}$ to the longitudinal dispersion coefficient, $\mathrm{E}$, of the river. Indeed, the dispersion increases significantly the rate of BOD exertion. Thus for a given temperature, the following relation is used:

$$
\mathrm{K}_{1}=\mathrm{K}_{1, \mathrm{l}} \mathrm{a}^{\mathrm{E}^{*} \mathrm{~b}}
$$

where

$a$ and $b$ are adjustable dimensionless parameters

$E$ is the longitudinal dispersion $\left(L^{2} \mathrm{~T}^{-1}\right)$

E can be calculated with empirical relations or determined experimentally on the river (using dyes such as rhodamine, for example).

The second formulation (Bosko, 1966; Novtony, 1969) replaces in equation (12.32) the multiplicative correction by an additive one. Thus the $\mathrm{BOD}$ exertion is more activated by the river, but caused partially by the river itself.

$$
\mathrm{K}_{1}=\mathrm{K}_{1, \mathrm{l}}+\mathrm{A}
$$

where $A$ is a kinetic coefficient describing absorption by biological slimes attached to a solid bottom or by dispersed biological flocs (Velz et al., 1962). Bosko proposed for coefficient A:

$$
A=n(v / H)
$$

where

$v$ is the river velocity $\left(\mathrm{L} \mathrm{T}^{-1}\right)$,

$\mathrm{H}$ is the river depth (L), and

$\mathrm{n}$ is a dimensionless coefficient of bed activity.

The last mentioned coefficient takes into account hydraulic parameters and chemical properties of the bed of the river. It is taken as a step function of the slope of the bed of the river (Table 12.2).

An alternative relation between coefficient $A$ and stream flow characteristics was proposed by Novtony (1969): 


$$
A=w * \frac{S_{e}^{1 / 6}}{H^{0.75}}
$$

where

$\mathrm{w}$ is a coefficient varying from 0.1 (streams with moving bottoms) to 3.0 (rocky streams)

$S_{e}$ is the slope of the river $(\mathrm{m} / \mathrm{km})$.

Table 12.2

Stream slope dependance of coefficient of bed activity $n$. After Bowie et al. (1985) $\quad K_{1}=K_{1, I}+n(v / H)$

\begin{tabular}{lcccc} 
Slope of the river $(\mathrm{km} / \mathrm{m})$ & 1.22 & 2.45 & 4.90 & 12.26 \\
\hdashline $\mathrm{n}$ & 0.10 & 0.15 & 0.25 & 0.40 \\
\hline
\end{tabular}

Novotny et al. (1975) compared equations (12.34) and (12.35) for different types of rivers, assuming that $K_{1}$ took into account a benthal oxygen demand (Table 12.3).

Two possibilities are available for determining a biodegradation kinetic constant: either calculate $\mathrm{K}_{1,1}$ through laboratory experiment and evaluate $K_{1}$ with one of the previously mentioned equations (12.34) or (12.35), or calculate directly $\mathrm{K}_{1}$ with a numerical optimisation technique or an statistical-experimental law.

Table 12.3

Comparison of experimental and calculated values of the $A$ coefficient, according to Bosco and Novotny, for Holston River, Tenessee. After Novotny et al. (1974)

\begin{tabular}{lcccccc}
$\begin{array}{l}\text { Character } \\
\text { of bottom }\end{array}$ & $\begin{array}{c}\text { Velocity } \\
(\mathrm{m} / \mathrm{s})\end{array}$ & $\begin{array}{c}\text { Depth } \\
(\mathrm{m})\end{array}$ & $\begin{array}{c}\text { Slope } \\
(\mathrm{m} / \mathrm{km})\end{array}$ & $\begin{array}{l}\text { A } \\
\text { Bosko }\end{array}$ & $\begin{array}{l}\text { A } \\
\text { Novotny }\end{array}$ & $\begin{array}{c}\text { Measured } \\
\mathrm{K}_{1}-\mathrm{K}_{1,1}\end{array}$ \\
\hline Gravel & 0.19 & 0.76 & 0.62 & 0.30 & 1.08 & 1.0 \\
Sand & 0.13 & 0.76 & 0.62 & 0.10 & 0.43 & 0.25 \\
Grav. rock & 0.52 & 0.58 & 0.50 & 1.34 & 1.90 & 2.12 \\
Grav. rock & 0.32 & 0.73 & 0.80 & 0.65 & 1.79 & 1.60 \\
Grav. rock & 0.29 & 0.73 & 0.234 & 0.59 & 1.34 & 1.14 \\
Grav. low poll. & 0.42 & 0.70 & 0.234 & 0.41 & 0.55 & 0.55 \\
Grav. low poll. & 0.27 & 1.86 & 0.234 & 0.12 & 0.22 & 0.15 \\
\hline
\end{tabular}




\section{Calculation of $\mathrm{K}_{1, \mathrm{I}}$}

a. Experimental study of BOD exertion.

The results of a BOD test in standard conditions (see paragraph 12.2) provides a DO versus time curve similar to that presented in Figure 12.2 (Wilderer et al., 1970). This curve frequently presents two plateaus, the first between 5 and 15 days, and the second one after 25 days. The first step with a quite marked slope corresponds to the carbonaceous degradation while the second corresponds to the nitrification stage of the biochemical degradation. Thus we see that the hypothesis of a first order reaction with a constant parameter $\mathrm{K}_{1, \mathrm{I}}$ is really an approximation. However, a first-order kinetic may be reasonably fitted during the first step of the experiment (before the curve reaches the first plateau): $K_{1,1}$ can be determined following DO uptake during 5 or 7 days, this last value being frequently preferred for practical considerations.

b. Graphical and mathematical procedures for determining $K_{1, r}$.

Before the general use of computers - before c.1965 - many authors developed graphical methods to determine the constant $K_{1}$. These all suppose that the biodegradation follows the first-order Streeter-Phelps kinetic law:

$$
C_{0}-C_{t}=L_{0}\left(1-\exp \left(K_{1, I}{ }^{*} t\right)\right)
$$

where

$C_{0}-C_{t}$ is the oxygen consumption at time $t\left(M^{-3}\right)$

$\mathrm{L}_{0}$ is the ultimate $B O D$ at time zero $\left(\mathrm{M} \mathrm{L}^{-3}\right)$

Hewitt et al. (1975) compared seven of these methods with 20 sets of data (Table 12.4). It is beyond the scope of this book to detail all of these methods, which have now been overtaken by other methods. The different approaches used by each author depend on the limitations inherent in the local conditions of the study (Bansal, 1975). The variation of the results lies between 0 and $50 \%$ depending to the method. However, according to Marske et al. (1972) who compared four of the previous methods, the Reed-Theriault method seems to give the best results. 
Table 12.14

Graphical and mathematical $\mathrm{K}_{1}$ procedures compared by Hewitt et al. (1975)

\begin{tabular}{llll} 
Name of the author & Name of the method & Date & Formulation \\
\hline Reed \& Theriault & Theriault & $1927-31$ & integral \\
Fair & Log-differences & 1936 & integral \\
Thomas & Slope & 1937 & differential \\
Rhame & Two point & 1957 & integral \\
Sheehy & Slide Rule & 1960 & integral \\
Moore & Moments & 1960 & integral \\
Navone & Simplified slope & 1960 & differential \\
\hline
\end{tabular}

c. Numerical methods for determining $K_{1,1}$.

The advent of the computer now allows the use of numerical optimization techniques for determining $\mathrm{K}_{1,1}$. More efficient than the graphical techniques, these methods allow checking of the validity of the results through confidence contour determination, for example. The most used method is a modified least-square method for non-linear problems (Marske et al., 1972; Berthouex, 1971; Balland, 1982). In the following, we note:

$\left(C_{0}-C_{t}\right)_{o b s}$ the observed value of DO consumed at time $t$,

$\underline{L} \quad$ the calculated value of $B O D$ exerted at time $t$, with the relation $\underline{L}=L_{0}\left(1-\exp \left(K_{1,1}{ }^{*} t\right)\right.$

$S=$ sigma $\left(\left(C_{0}-C_{t}\right)_{o b s}-\underline{L}\right)$, over 1 the number of observations.

Because of the non-linearity of the problem a search is conducted with an iterative algorithm for $L_{0}$ and $K_{1, l}$ which minimize $S$. If $S$ remains high even when these $L_{0}$ and $K_{1,1}$ values represnet the best fit for the observed data - calculated data, the first-order law does not represent the observed phenomena well. The confidence contour around the best estimate are those for which $S\left(L_{0}, K_{1, l}\right)=$ constant. Although this problem is non-linear, a confidence level: $100(1-$ q) $\%$ associated to a confidence contour can be defined:

$$
S_{q}=S\left(L_{0}, K_{1, I}\right)(1+(p / l-p) \quad F(p, I-p, 1-q))
$$

with $p$ the number of parameters for the model, 
1 the number of observations

$\mathrm{q}$ the confidence level

For $p=2 ; \quad F(2,1-2,1-q)=1-2 / 2\left(q^{-2 / 1-2}-1\right)$

$S_{\mathrm{q}}=\mathrm{S}\left(\mathrm{L}_{\mathrm{o}}\right.$ and $\left.\mathrm{K}_{1, \mathrm{I}}\right) * \mathrm{q}^{-2 / 1-2}$

Since this method gives the best parameters $K_{1,1}$ and $L_{0}$ or $K_{1, l}$ and $B O D_{5}$ for each sample, it is possible to improve it and then to simplify the $K_{1,1}$ calculation, searching a regression relation between the two parameters (linear or $\log -\log$ ). Thus with this relation, valid at a certain location, it becomes possible to calculate $\mathrm{K}_{1,1}$ with a simple measure of $\mathrm{BOD}_{5}$ (Balland, 1982).

Marske et al. (1972) compared this technique with three of the previously mentioned graphical methods, and plotted their results as the percentage of the distance from the best fit of $\mathrm{K}_{1,1}$ vs ultimate BOD (Figure 12.3). It will be noticed that the graphica! Reed-Theriault method gives as good results as the numerical least-squares method.

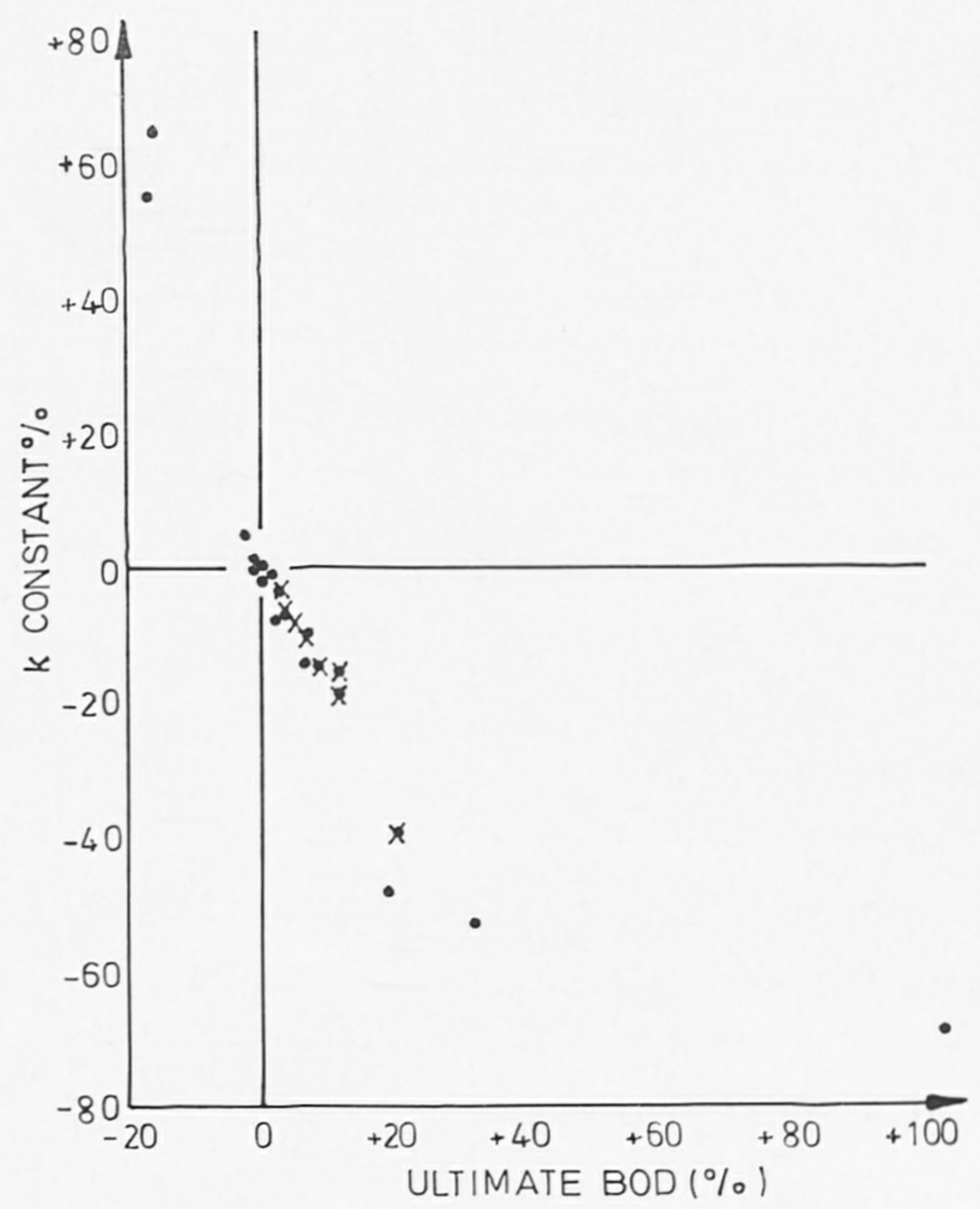

Fig. 12.3: Biodegradation kinetic constant determination: deviation from the best estimate. After Marske et al., 1972.

o: Method of Moments, x: Thomas Slope Method, $\bullet:$ Log-difference Method. 
d. Order of magnitude of $K_{1}$

Table 12.5 presents some deoxygenation rate constants $\mathrm{K}_{1}$ observed for different locations and temperatures, in the United States. From these values it is clear that $\mathrm{K}_{1}$ may vary over more than one order of magnitude.

Table 12.5

Deoxygenation rate constants $K_{1}$. After Bansal (1975)

\begin{tabular}{|c|c|c|c|c|c|}
\hline & $\begin{array}{l}\text { Discharge } \\
\left(\mathrm{m}^{3} / \mathrm{s}\right)\end{array}$ & $\begin{array}{l}\text { Section } \\
\left(m^{2}\right)\end{array}$ & $\begin{array}{l}\text { Top width } \\
\text { (m) }\end{array}$ & $\begin{array}{l}\text { Temperature } \\
\left({ }^{\circ} \mathrm{C}\right)\end{array}$ & $\begin{array}{c}\mathrm{K}_{1} \text { (base e) } \\
\text { (I/day) }\end{array}$ \\
\hline \multicolumn{6}{|l|}{ Kansas River at Bonner Springs } \\
\hline & 430.416 & 399.483 & 234.696 & 25.000 & 0.020 \\
\hline & 61.164 & 111.464 & 153.924 & 28.000 & 0.120 \\
\hline \multirow[t]{2}{*}{ Kansas River at Topeke } & 86.083 & 134.709 & 142.646 & 22.000 & 0.080 \\
\hline & 76.172 & 119.380 & 142.037 & 18.000 & 0.370 \\
\hline \multirow[t]{2}{*}{ Big Blue River at Tuttle Creek } & 30.016 & 97.548 & 59.131 & 22.000 & 0.210 \\
\hline & 27.212 & 92.903 & 59.131 & 8.000 & 0.600 \\
\hline \multirow[t]{2}{*}{ Republican River below Milford } & 7.306 & 17.094 & 59.741 & 24.000 & 0.180 \\
\hline & 17.243 & 36.418 & 75.795 & 24.000 & 0.070 \\
\hline \multirow[t]{2}{*}{ Smoky Hill River at Enterprise } & 10.562 & 19.603 & 39.929 & 24.000 & 0.160 \\
\hline & 4.446 & 8.175 & 29.566 & 14.000 & 0.240 \\
\hline \multirow[t]{3}{*}{ Flint River. Michigan } & 3.794 & 19.510 & 30.480 & 20.000 & 0.560 \\
\hline & 4.927 & 37.161 & 46.878 & 20.000 & 0.690 \\
\hline & 4.927 & 18.581 & 23.439 & 2.000 & 0.630 \\
\hline \multirow[t]{2}{*}{ Upper Hudson, Troy, New York } & 84.951 & 557.416 & 104.546 & 20.000 & 0.125 \\
\hline & 127.426 & 627.096 & 97.841 & 20.000 & 0.165 \\
\hline
\end{tabular}

\section{Determination of $\mathrm{K}_{1}$ or $\mathrm{K}_{1, \mathrm{r}}$ by direct methods}

\section{a. Statistical experimental method}

The aim of this method is to determine $K_{1}$ without use of any relation between $\mathrm{K}_{1, l}$ and $\mathrm{K}_{1}$. As the river flow may be characterized by Froude ( $\mathrm{Fr}$ ) and Reynolds (Re) numbers, Bansal (1975), tried to relate, on the basis of data gathered by the E.P.A., $\mathrm{K}_{1}, \mathrm{Re}$ and $\mathrm{Fr}$. The following relation was found with a correlation coefficient of 0.93 and a standard deviation of 0.41 .

$$
\log \left(K_{1}{ }^{*} H^{2} / n u\right)=3.606+\log (\operatorname{Re} / F r)
$$

with 


$$
\begin{aligned}
& \mathrm{Re}=v^{*} \mathrm{H} / \mathrm{nu} \\
& \mathrm{Fr}=v /\left(g^{*} H\right)^{1 / 2}
\end{aligned}
$$

where
$\mathrm{nu}$ is the kinematic viscosity coeffcient $\left(\mathrm{L}^{2} \mathrm{~T}^{-1}\right)$
$\mathrm{H}$ is the depth of the river (L)
$\mathrm{g}$ is the acceleration of gravity $\left(\mathrm{L} \mathrm{T}^{-2}\right)$

The temperature influence is included into the variation of nu with temperature. It is also possible to use this relation at $20^{\circ} \mathrm{C}$ and then use Arrhenius law. The major advantage of this method is its simplicity. It may be possible to use a Streeter-Phelps model with good accuracy, without any knowledge of the location of the river or the pollution. This is very useful for fast diagnosis of the biodegradation in a river.

\section{b. Determination of $K_{1}$ or $K_{1, r}$ with manual or automatic calibration}

These methods are no longer based on laboratory BOD test. Now the computer is considered as a numerical laboratory and after seting the model description (simple with Streeter-Phelps first-order kinetics), parameter values are determined for achieving the best fit between the observed and calculated data along the river. The fact that either $K_{1}$ or $K_{1, r}$ are determined depends on the previous analysis of the system which is being modelled. If just the BOD exertion is taken into account, then $K_{1}$ will be found. If $\mathrm{BOD}$ exertion and $\mathrm{N}-\mathrm{NH}_{4}{ }^{+}$nitrification in water and on the sediments, and the respiration and photosynthesis are taken into account, then $K_{1, r}$ will be found.

\section{b.1 Manual methods}

The simplest way, for a simple Streeter-Phelps model, with just two parameters, is to simulate the behaviour of the river for different sets of parameters until a good adjustment between experimental and simulated values is observed (Lesouef, 1980). Although this method is especially rough, it can be very helpfull and it provides good results if the model remains simple.

\section{b.2 Numerical methods}

If the model is a more complicated one, the difficulty of manual parameter estimation increases. The only way which can be used is an automatic calibration procedure. Two strategies are available for a numerical calculation of the estimate (Rinaldi et al., 1980): the recursive and the 
accumulative estimation. Accumulative procedures are designed for calculating estimates from a fixed set of data, while recursive schemes are suited for estimates which are to be updated as new information becomes available. While the first method is used when the parameters are not supposed to vary in time, the second one is very usefull for real time state estimation. Since BOD measurements need a minimum of 5 days, the utilization of such a method in biodegradation remains rare.

\section{b.2.1 Accumulative procedures}

These procedures are based on an error estimator function to minimize, for example, a least squares estimator. Various numerical methods are available to solve a minimization problem, such as the quasi-linearization technique (Stehfest, 1973), which has the advantage of a fast convergence rate. These accumulative techniques are now much used (Shastry et al., 1973; Rinaldi, 1979; Radhakrishnan et al., 1974), and allow the building of sophisticated models with many parameters. After a successful calibration the set of parameters found has to be validated on another set of data.

\section{b.2.2 Recursive procedures}

The recursive procedures are based on stochastic mechanistic models. The problem is to determine the state estimation for the time interval, $t_{s}$, from the input - output measurement for the previous intervals $\left(0<t<t_{s}\right)$. Parameter estimation can be done with the well known numerical technique of Kalman filtering, or another method which appears to provide an improvement in statistical efficiency - the multivariate extension of the Instrumental Variable Approximate Maximum Likehood (IVAML) method of time series analysis (Whitehead et al., 1979). This procedure has been successfully applied to the real-time monitoring scheme of the River Ouse at Bedford on a modified Streeter-Phelps model (DO, N- $\mathrm{NH}_{4}{ }^{+}$) (Whitehead, 1983).

\subsection{FUTURE RESEARCH NEEDS}

Difficulties encountered in modelling microbial decomposition of organic matter are possibilities of descriptive or interpretative mathematical models and relation between the model structure and its applications.

Experimental and field research needs for microbial decomposition models: differences between intrinsic parameters and parameters fitted from field data, difficulties arising from non-linear kinetics. 


\section{ACKNOWLEDGMENTS}

The help of Mrs Gamrasni, from I'Association Française de l'Etude des Eaux, Paris, is greatly acknowledged.

\section{NOTATIONS}

A

ATP

$\mathrm{B}$

$\mathrm{BOD}$

C

$\mathrm{C}_{\mathrm{s}}$

$\infty O D$

D

$\mathrm{D}_{\mathrm{b}}$

$D_{c}$

DNA

DO

$\mathrm{dR}_{0} / \mathrm{dt}$

E

F

$\mathrm{Fr}$

$f$

g

$\mathrm{H}$

$\mathrm{K}_{1}$

$\mathrm{K}_{1, \mathrm{I}}$

$\mathrm{K}_{1, \mathrm{r}}$

$\mathrm{K}_{1, \mathrm{~s}}$

$\mathrm{K}_{1, \mathrm{NH} 4}$

$\mathrm{K}_{\mathrm{NR}, \mathrm{NH} 4}$

$\mathrm{K}_{1, \mathrm{NO} 2}$

is an additional coefficient describing the augmentation of $\mathrm{K}_{1,1}$ in natural sites $\left(\mathrm{T}^{-1}\right)$ adenosine triphosphate biomass concentration $\left(\mathrm{M} \mathrm{L}^{-3}\right)$ biochemical oxygen demand $\left(\mathrm{M} \mathrm{L}^{-3}\right)$ dissolved oxygen concentration $\left(\mathrm{M} \mathrm{L}^{-3}\right)$ saturated dissolved oxygen concentration $\left(\mathrm{M} \mathrm{L}^{-3}\right)$ chemical oxygen demand $\left(\mathrm{M} \mathrm{L}^{-3}\right)$ dissolved oxygen deficit, i.e. $\mathrm{C}_{\mathrm{s}}-\mathrm{C}\left(\mathrm{M} \mathrm{L}^{-3}\right)$ rate of removal of DO caused by benthic demand and plants $\left(\mathrm{M} \mathrm{L}^{-3}\right)$ critical dissolved oxygen deficit, i.e. maximum of $D\left(\mathrm{M} \mathrm{L}^{-3}\right)$ deoxyribonucleic acid dissolved oxygen rate of reoxygenation $\left(\mathrm{M} \mathrm{L}^{-3} \mathrm{~T}^{-1}\right)$ turbulent transport (longitudinal mixing) coefficient $\left(\mathrm{L}^{2} \mathrm{~T}^{-1}\right)$ source or drain of organic pollutant $\left(\mathrm{M} \mathrm{L}^{-3}\right)$

Froude number (dimensionless)

Fair coefficient, also called self-purification factor, i.e. $\mathrm{K}_{2} / \mathrm{K}_{1}$ (dimensionless)

acceleration of gravity $\left(\mathrm{L} \mathrm{T}^{-2}\right)$

depth (L)

biodegradation kinetic constant in first-order kinetic models, i.e. water deoxygenation rate due to BOD exertion $\left(\mathrm{T}^{-1}\right)$ laboratory deoxygenation rate due to $\mathrm{BOD}$ exertion $\left(\mathrm{T}^{-1}\right)$ water exertion rate of $\mathrm{BOD}$, includes all sinks of $\mathrm{BOD}\left(\mathrm{T}^{-1}\right)$ kinetic constant of BOD evolution on sediments $\left(\mathrm{T}^{-1}\right)$ ammonia biodegradation (oxidation) kinetic constant in first-order nitrification kinetic models $\left(\mathrm{T}^{-1}\right)$ ammonium uptake kinetic constant in first-order kinetic models $\left(\mathrm{T}^{-1}\right)$ nitrite biodegradation (oxidation) kinetic constant in first-order 
kinetic models $\left(\mathrm{T}^{-1}\right)$

$\mathrm{K}_{2} \quad$ oxygen transfer kinetic constant, also called reaeration kinetic constant $\left(\mathrm{T}^{-1}\right)$

$\left(\mathrm{K}_{2}\right)_{20}$ value of $\mathrm{K}_{2}$ at $20^{\circ} \mathrm{C} \quad\left(\mathrm{T}^{-1}\right)$

$\mathrm{L}$

$L_{\circ}$

$L_{a}$

I

$\mathrm{NH}_{4}-\mathrm{N}$

$\mathrm{NO}_{2}-\mathrm{N}$

$\mathrm{n}$

OM

$P$

$\mathrm{P}_{\mathrm{m}}$

P

Q

$Q_{T}$

$q$

$\mathrm{R}$

Re

$S$

$\mathrm{S}_{\mathrm{e}}$

$\mathrm{S}$

T

t

$t_{s}$

TOC

TOD

V

v

w

$\mathrm{X}$

Y

$\mathrm{mu}$

$\mathrm{mu}_{\mathrm{M}}$

$\mathrm{nu}$

ro

concentration of organic matter, generally expressed in ultimate $\mathrm{BOD}$ and frequently related to carbonaceous compounds $\left(\mathrm{M} \mathrm{L}^{-3}\right)$ initial value of ultimate $\mathrm{BOD}\left(\mathrm{M} \mathrm{L}^{-3}\right)$ rate of $B O D$ release along a river length unit $\left(\mathrm{M} \mathrm{L}^{-4}\right)$ number of observations (dimensionless) ammonium nitrogen concentration $\left(\mathrm{M} \mathrm{L}^{-3}\right)$ nitrite nitrogen concentration $\left(\mathrm{M} \mathrm{L} \mathrm{L}^{-3}\right)$ coefficient of bed activity (Bosko, 1966) (dimensionless) organic matter algal photosynthetic oxygen production rate (source) $\left(\mathrm{M} \mathrm{L}^{-3} \mathrm{~T}^{-1}\right)$ maximum algal photosynthetic oxygen production rate (source) $\left(M^{-3} \mathrm{~T}^{-1}\right)$ number of parameters of the model flow rate (downstream) $\left(\mathrm{L}^{3} \mathrm{~T}^{-1}\right)$

thermal air-water energy transfer rate confidence level

algal respiration rate (oxygen sink) $\left(\mathrm{M} \mathrm{L}^{-3} \mathrm{~T}^{-1}\right)$

Reynolds number (dimensionless)

benthic respiration rate (oxygen sink) $\left(\mathrm{M} \mathrm{L}^{-3} \mathrm{~T}^{-1}\right)$

slope of the river (dimensionless or $\mathrm{m} / \mathrm{km}$ )

period of sunlight, i.e. fraction of the day at which photosynthesis is active ( $T$ )

temperature of the water $\left({ }^{\circ} \mathrm{C}\right)$

time $(T)$

time, expressed as a fraction of the day, at which oxygen photosynthesis becomes active ( $T$ )

total organic carbon $\left(\mathrm{M} \mathrm{L}^{-3}\right)$

total oxygen demand $\left(\mathrm{M} \mathrm{L}^{-3}\right)$

volume $\left(L^{3}\right)$

velocity (downstream) $\left(\mathrm{LT} \mathrm{T}^{-1}\right)$

coefficient of bed activity (Novotny, 1969)

distance (downstream) (L)

biomass yield from organic matter (dimensionless)

bacterial growth rate $\left(\mathrm{T}^{-1}\right)$

maximal growth rate $\left(\mathrm{T}^{-1}\right)$

kinematic viscosity coefficient $\left(\mathrm{L}^{2} \mathrm{~T}^{-1}\right)$

water specific mass $\left(\mathrm{M} \mathrm{L}^{-3}\right)$ 
pi 3.1416

theta temperature coefficient of $\mathrm{K}_{1}$ (dimensionless)

phi temperature coefficient of $\mathrm{K}_{2}$ (dimensionless)

\section{REFERENCES}

Alfi S., Argaman Y. and Shelef G. (1972). Mathematical model for the prediction of dissolved oxygen levels in the Alexander Stream (Israel), Proc. 6th Int. Water Pollution Research (17) C 8/17/1-8.

Apoteker A. (1981). Réactions de biodégradation en rivière. Evolution de l'oxygène dessous, de la charge polluante et de la biomasse, Thèse de $3 \mathrm{e}$ Cycle, Université Paris-Val de Marne, Créteil, France, 212 p.

Apoteker A. and Thévenot D.R. )1983). Experimental simulation of biodegradation in rivers. Oxygen, organic matter and biomass concentration changes, Water Res., 17 (10) 1267-1274.

Arbabi M., Elzinga J. and Revelle C. (1974). The oxygen sag equation: new properties and a linear equation for the critical deficit, Water Res., 10 (5) 921-929.

Arbabi M. and Elzinga J. (1975). A general linear approach to stream water quality modeling, Water Res., 11 (2) 191-195.

Blok J. (1975). Methods for measurement of biodegradability of chemical compounds. Int. Biodetn. Bull., 11 (3) 78-84.

Balland $P$. (1982). Méthode d'estimation numérique du coefficient $K_{1}$ de dégradation biochimique de le DBO, T.S.M. l'eau, 3 157-161.

Bansal M.K. (1975). Deoxygenation in natural streams. Water Resources Bulletin, 11 (3) 491-504.

Berthouex P.M. and Hunter W.G. (1971). Problems associated with BOD planning experiments, Jour. San. Eng. Div. proc ASCE, 97 (SA3) 333-343.

Boethling R.S. and Alexander M. (1979). Microbial degradation of organic compounds at trace levels. Envir. Sci. Technol., 13 (8) 989-991.

Bosko K. (1966). Discussion to paper I-1, Advances in water pollution research, Pergamon Press, Oxford, $\underline{3}$

Bowie G.B., Mill W.B., Porcella D.B., Campbell C.L., Pagenkopf J.R., Rupp G.L., Johnson K.M., Chan P.W.H., Gherini S.A. and Chamberlin C.E. (1985). Rates, constants and kinetics formulations in surface water quality modeling. Second edition, Tetra-Tech, Lafayette, California, EPA/600/3-85/040.

Churchill M.A., Elmore H. and Buckingham R. (1962). The prediction of stream reaeration rates, Jour. San. Eng. Div. proc. ASCE, 88 (SA4) 1-46.

Clark D.W. (1974). BOD: a re-evaluation, Water and Sewage Works, $\underline{5}, 68-69$.

Covar A.P. (1976). Selecting the proper reaeration coefficient for use in water quality models, Presented at the U.S. EPA Conference on Environmental Simulation and Modeling, April, 19-22.

Dart R.K. and Stretton R.J. (1980). In: Microbiological aspects of pollution control, Chap. 11. Biodegradation, 2nd ed., Elsevier, Amsterdam, pp. 216-256.

Dobbins W.E. (1964). BOD and oxygen relationships in streams, J. Sanit. Engng. Div. Am. Soc. civ. Engrs 90, SA3, 53-78.

Eckenfelder W.W.Jr. (1970). Water quality engineering for practicing 
engineers, Barnes and Noble, New York.

Edeline F. and Buet J.L. (1978). $\$ \$ \$ \$ \$ \$ \$ \$ \$$, La Tribune du Cebedeau, 415-416, 273-280.

Edeline F. and Lambert G. (1974). A simple simulation method for river self-purification studies, Water Res., 8, 297-306.

Edeline F. and Lambert G. (1979). Self purification of rivers: a two phase model for bacterial degradation, Water Res., 13, 473-480.

Fair G.M. and Gordon M. (1936). The Log-difference method of estimating the constants of the first BOD stage curve, Sewage Works Journal, $\underline{8}$ (3) 430-434.

Flegal T.M. and Schroeder E.D. (1976). Temperature effects on BOD stoichiometry and oxygen uptake rate, J. Wat. Pollut. Control Fed., 48, 2700-2707.

Gates W.E. (1971). Laboratory and mathematical simulation of oxygen balances effected in streams, School Civil Engng. Envir. Res. Center, Georgia Inst. of Technology, Atlanta, Georgia, ERC-0171, 52 p.

Gaudy A.F. (1972). In: Water pollution microbiology, Chap. 13, Biochemical oxygen demand, R. Mitchell ed., Wiley Intersciences, New York, pp. 305-332.

Green M., Shelef G. and Moraine R. (1981). Chemical and biochemical oxygen demands as indicators of biodegradable substrate concentration, Water Pollut. Control Fed., 80 (5) 655-658.

Gromiec M.J., Loucks D.P. and Orlob G.T. (1983). Stream quality modeling, In: Mathematical modeling of water quality: streams, lakes and reservoirs, G.T. Orlob ed., International Series on Applied Systems Analysis, 12, Wiley Interscience, New York, pp. 176-226.

Gromiec, M.J., 1983. Biochemical oxygen demand - dissolved oxygen: river models, In: Application of Ecological Modelling in Environmental Management, Part A, S.E. Jørgensen, ed. Elsevier Scientific Publishing Company, Amsterdam, pp. 131-225.

Hewitt J.P. and Hunter J.V. (1975). A comparison of methods used to calculate first-order BOD equations constants, Water Research, $\underline{9}$, 683-687.

Holm-Hansen O. (1970). ATP levels in algal cells as influenced by environmental conditions, PI. Cell Physiol., 11, 689-700.

Hung Y.-T. and Eckenfeld W.W. (1976). Comparison of Warburg and Marais methods for determining oxygen uptake rate constants, Water Pollution Control, 114 (2) 6-25.

Hung Y.-T., Eckenfelder W.W. and Reynolds T.D. (1978). Effect of treatment and flow on the deoxygenation rate constant, Water Air Soil Pollut., 10 (2) 175-185.

Hydroscience (1964). Assimilation capacity of the upper James River, State Water Control Board Commonwealth of Virginia.

Hydroscience (1965). Pollution analysis of the Upper Hudson River estuary, Malcolm Pirnie Engineers.

Hydroscience (1966). Water quality studies New River Celanese Corp. of America, Celco Plant, Narrows, Virginia.

Hydroscience (1967). Water quality analysis of the Jackson River, West Virginia Pulp and Paper Company, Covington.

Illic P. (1978). Biochemischer Sauerstoffbedarf. Die Rolle des $\mathrm{CO}_{2}$ bei der Respirometrischen Bestimmung, Wasser Luft Betr., 22 (1-2), 20-21.

Jacquet J. (1983). Simulation of the thermal regime of rivers, In: Mathematical modeling of water quality: streams, lakes and reservoirs, 

oxygen in streams, Water Resour. Bull., 3, 65-79.

O'Connor D.J. and Di Toro D.M. (1970). Photosynthesis and oxygen balance in streams, J. Sanit. Engng. Div. Soc. Civ. Engrs., 96 (SA2) 547-571.

Orlob G.T. (1983). One-dimensional models for simulation of water quality in lakes and reservoirs, In: Mathematical modeling of water quality: streams, lakes and reservoirs, G.T. Orlob ed., International Series on Applied Systems Analysis, 12, Wiley Interscience, New York, pp. 227-273.

Owens M., Edwards R.W. and Gibbs J.W. (1964). Some reaeration studies in streams, Int. Jour. Air and Water Poll., $8 \underline{8} 469$.

Radhakrishnan K.P., Lizcano J.J., Erickson L.E. and Fan L.T. (1974). Evaluation of methods for estimating stream water quality parameters, in a transient model from stochastic data, Water Resources Bulletin, 10 (5) 899-913.

Rauwel F. and Thévenot D.R. (1976). Comparison of dissolved oxygen evolution after thermal and pollution discharge. Final contract report for Agence Financière de Bassin Seine Normandie, $50 \mathrm{p}$.

Reed L.J. and Theriault E.J. (1931). The statistical treatment of reaction-velocity data I,II, Jour. Phys. Chem. 35 673, 950.

Remiche C. and Van Der Wielen (1975). Quelques considérations concernant I'utilisation du "Sapromat" pour la mesure de la toxicité. Trib. Cebedeau, 381-382 (8-9) 314-319.

Revelle C.S., Lynn W.R. and Riviera M.A. (1965). Biooxidation kinetics and a second order equation describing the BOD reaction, J. Wat. Pollut. Control Fed., 37, 1679.

Rhame G.A. (1956). A two point method for estimating the first stage BOD, Sewage and Industrial wastes 28 (9) 1987-1093.

Rinaldi S. and Soncini-Sessa R. (1977). Sensitivity analysis of Streeter-Phelps models, Intern. Inst. Applied Syst. Anal., Laxenburg, Austria, RR 77-1, 18 p.

Rinaldi S., Soncini-Sessa R., Stehfest H. and Tamura H. (1979). Modeling and control river quality, Mac-Graw Hill, New York, 380 p.

Shastry J.S., Fan L.T. and Erickson L.E. (1973). Non-linear estimation in water-quality modeling. Jour. Env. Eng. Div. proc. ASCE, 99 (ee3) 315-331.

Sheeny J.P. (1960). Rapid method for solving first-order equations, J.W.P.C.F. 32 (6) 646-652.

Shelton S.P., Burdick J.C. III and Drewry W.A. (1978). Water quality modeling in a low flow stream, J. Wat. Pollut. Control Fed., 50 2289-2306.

Stack V.T. (1972). In: Water and water pollution handbook, Vol. 3, Chap. 15, Biochemical oxygen demand measurement, L.L. Ciaccio ed., Dekker, New York, pp. 801-829.

Stack V.T. (1973). Stabilization oxygen demand, in Biological Methods for the assessment of Water Quality, ASTM STP 528, Amer. Soc. for Testing and Materials, 209-220.

Stehfest H. (1973). Mathematical modelling of self-purification of rivers (in German), report KFK 1654 UF, Kernforschungzentrum, Karlsruhe.

Streeter H.W. and Phelps E.B. (1925). A study of the pollution and natural purification of the Ohio River, Public Health Bulletin 146, Washington D.C.

Streeter H.W., Wright C.T. and Kehr R.W. (1936). Measures of natural oxidants in polluted streams II, Sewage Works Journal, 8282.

Theriault E.T. The oxygen demand of polluted waters, Public Health Service Bulletin, U.S. Public Health Service, Washington D.C., 173.

Thomas H.S. Jr. (1937). The slope method of evaluating the constants of the first stage BOD curve, Sewage Works Journal, $\underline{9}$ (3) 425-430. 
Truesdale G.A. and Van Dyke K.G. (1958). The effect of temperature on the aeration of flowing waters, Water and Waste Treatment Journal 79.

Tobin R.S., Ryan J.F. and Afghan B.K. (1978). An improved method for the determination of adenosine triphosphate in environmental samples, Water Res., 12, 783-792.

Velz C.J. and Gannon J.J. (1962). Biological extraction and accumulation in stream self-purification, Advances in Water pollution research, Pergamon Press, Oxford.

Whitehead P.G. (1983). Modeling and forecasting water quality in non-tidal rivers: the Bedford Ouse study, In: Uncertainty and forecasting of water quality, Beck M.B. and Van Straten G. eds., Springer-Verlag, Berlin, $321-337$.

Whitehead P.G. and Young P.C. (1979). Water quality in rivers systems: Monte-Carlo analysis, Water Resources Research, 15 (2) 451-459.

Wilderer P., Hartmann L. and Janeckova J. (1970). Objections against the use of long-term BOD for characterizing raw waste water (in German). Wasser- und Abwasser-Forschung, 1 7-12.

Woodward R.L. (1953). Deoxygenation of sewage. A discussion, Water Res., 12 , 783-792.

Wuhrmann K. (1972). In: Water pollution Microbiology, Chap. 6. Stream purification, Mitchell R. ed., Wiley-Interscience, New York, pp. 119-151.

Young J.C. and Clark J.W. (1965). Second order equation for BOD, J. Sanit. Engng. Div. Am. Soc. civ. Engrs. 91, SA1, 43.

Zanoni A.E. (1967). Waste water deoxygenation at different temperatures, Water Res., 1, 543. 